\title{
Association Between Typhoid and Paratyphoid Fever with ABO Blood Group among Patients Attending Raparin Pediatric Hospital in Erbil
}

\author{
Khanzad Hadi Alchawishli (MSc) ${ }^{1}$, Sadiya Abdulla Palpitany (MSc) ${ }^{2}$, Banaz Sadiq
} Smail $(\mathrm{MSc})^{3}$ and Shukir Salem Hassan $(\mathrm{PhD})^{4}$

\section{Abstract}

Background: The ABO blood groups and Rhesus factor are different in their susceptibility and resistance to various diseases. The role of $\mathrm{ABO}$ blood group has long been a subject of investigation and debate. Typhoid and paratyphoid disease is commonly encountered a systemic disease caused by gram negative bacteria Salmonella typhi and Salmonella paratyphi. Because of the presence of favorable predisposing factors for transmission of typhoid disease among children in Kurdistan.

Objective: To find the occurrence of Salmonella typhi and Salmonella paratyphi among children, with their distribution among different blood groups.

Patients and Methods: A cross-sectional study was carried out on 300 subjects were randomly selected from children who were likely to be infected with typhoid or paratyphoid fever in Raparin Teaching Hospital in Erbil. Blood sample were taken for performing ABO blood grouping, widal test and blood cultures.

Results: Result of the study reveals $(31.33 \%)$ and $(34.33 \%)$ of children were infected with Salmonella typhi and Salmonella paratyphi. The highest typhoid/paratyphoid was observed among blood group $\mathrm{O}$, thus it was most susceptible group. The least was noticed among blood group $\mathrm{AB}$ children which is the most resistant.

Conclusion: Results have revealed significant association between ABO blood group and susceptibility to typhoid/paratyphoid infections.

Keywords: Typhoid fever, Paratyphoid fever, ABO blood group, Rh factor.

Corresponding Author: Khanzad.rashid@hmu.edu.krd

Received: $17^{\text {th }}$ March 2019

Accepted: $10^{\text {th }}$ June 2019

DOI:https://doi.org/10.26505/DJM.17024590317

1,2,3,4 College of Nursing - Hawler Medical University-Erbil-Iraq.

\section{Introduction}

Salmonella enterica serotype Typhi and Paratyphi A and B are human-restricted pathogens and are the causes of enteric fever.Typhoid fever is a commonly encountered systemic disease caused by the gram negative bacteria Salmonella entericaserovertyphi, Salmonella enterica serotype Typhi (S. Typhi) infection causes 
approximately 20 million cases of enteric (typhoid) fever and over 200,000 deaths annually [1]. Salmonella enterica serotype Paratyphi A (S. Paratyphi A) infection causes an additional [5] million cases of enteric (paratyphoid) fever each year [1,2].

Typhoid fever is one of the major health problems in the developing countries, because many interrelated factors, including increased urbanization, inadequate supplies of clean water, antibiotic resistance, the variable efficacious of vaccine preparations, also increased regional movement of large number of migrants [3], and outbreaks are more common in summer season [4]. World health Organization (WHO) Identifies Typhoid as serious public health problem and its incidence is highest in children and young adults between 5-19 years old. Therefore Salmonella typhi represents the commonest cause of bacteremia in this age group [5].

The blood group antigens present on RBC are permanent, fixed and lifelong biological markers of any individual, they are almost as individual as fingerprints [6]. The distribution of the $\mathrm{ABO}$ blood groups varies in populations throughout the world [7]. In addition to clinical significance for transfusion and transplantation, it is becoming increasingly apparent that $\mathrm{ABO}$ antigens are of biological significance and may be associated with predisposition to, or protection from many diseases [8]. The importance of this study due the facts in Kurdistan which helps in the transmission of this disease, including in adequate electricity generating plants, water purification and sewage treatment plants these coupled with overcrowded of large number of migrants. In an adequate supplies of sanitation facilities especially with the last war and crises, all these factors may lead to increase cases of typhoid fever. High prevalence of Salmonella had been found during 2013 among infants and children in Erbil city [9]. The objectives of this study were to find out the occurrence of Typhoid and paratyphoid among children, also to demonstrate the distribution of Typhoid and Paratyphoid fever among different blood groups, and to detect the association between typhoid and paratyphoid with ABO blood groups.

\section{Patients and Methods}

A cross-sectional study was conducted at Raparin Teaching Hospital for Pediatric in Erbil City, after the study was approved by the research ethics committee of Hawler Medical University /College of Nursing. A total of 300 children were visited the hospital during June 2017 to September 2018 aged between 1 to 12 years old, and suspected to have typhoid fever after physician's examination. Permission was taken from their parents to participate in this study. A questionnaire was designed which include socio-demographic characteristics, educational level, and important symptoms of typhoid. Children were divided into three groups according to their ages which were toddler age (1-3 years), preschool age (3-6 years) and the school age (6-12 years).

Blood sample: A single blood sample was collected from each child; each sample composed of $6 \mathrm{ml}$ of blood was drawn 
aseptically by vein puncture using disposable syringes.

\section{Blood grouping}

$\mathrm{ABO}$ blood group and $\mathrm{Rh}$ factor test were done directly after blood collection in biology lab of Raparin Hospital, Blood grouping was done by commercial reagent kit (Atlas, Cambridge), and tests were performed by agglutination method. This kit contains Anti-A, Anti-B and Anti-D. A drop of anti-A, anti-B and anti-D were added to each drop of blood on clean slide and mixed well. Results of agglutination were recorded for $\mathrm{ABO}$ blood groups and $\mathrm{Rh}(\mathrm{D})$.

\section{Widal test}

Two milliliter of blood was placed in plastic disposable tubes, it was left to stand at room temperature $\left(25^{\circ} \mathrm{C}\right)$ to allow it to clot, next the sera was separated by centrifugation for 5 minutes then it was subjected to the widal procedure by pipetting $0.08 \mathrm{ml}$ of serum and dropped on a sterile slide in four different part for Salmonella typhi $\mathrm{O}$ and another for Salmonella paratyphi $\mathrm{H}$ antigen Antigen $\mathrm{O}$ and $\mathrm{H}$ were shaken and dropped to serum accordingly, then mixed and rocked gently for two seconds finally the result recorded depending on the gravity of agglutination $1 / 20$ considered negative while $1 / 80$ and 1/320 were positive [10].

\section{Blood culture}

Three milliliter of the drawn blood was directly subjected to the culturing by putting into $18 \mathrm{ml}$ thioglycolate broth and incubated at $37{ }^{\circ} \mathrm{C}$ for 48 hours then sub cultured into salmonella-Shigella Agar (SS-agar) samples regarded as negative and discarded if there were no growth in the media after 7-10 days which led to the discarding false positive recorded widal test for same samples. Then identification had done for positive cultures depending on standard culture, microscopic (Grams stain), motility and biochemical characteristics were done to confirm presence of salmonella. Biochemical test like citrate utilization test, Catalase, coagulase, glucose and lactose fermentation tests...etc. Procedures of test were done by Cheesbrough [11].

\section{Statistical analysis}

Analysis of the data was performed using social package statistical science (SPSS) version 23. Chi square tests for association between variables (typhoid/ paratyphoid and blood groups) with probability values ( $p$ values) calculated at the 0.05 level of significance.

\section{Results}

Table (1): Distribution of developmental stage of patients among gender

\begin{tabular}{||l||l|l||}
\hline \multirow{2}{*}{ Developmental stage (Years) } & \multicolumn{2}{c|}{ Gender } \\
\cline { 2 - 3 } & \multicolumn{1}{|c|}{ Male No. (\%) } & Female No. (\%) \\
\hline \hline Toddler stage (1-3) & $29(9.67)$ & $23(7.67)$ \\
\hline \hline preschool age (3-6) & $35(11.67)$ & $23(7.67)$ \\
\hline \hline School age (6-12) & $46(15.33)$ & $144(47.99)$ \\
\hline \hline Total & $110(36.67)$ & $190(63.33)$ \\
\hline
\end{tabular}


Three hundred patients were enrolled in this study between May 2016 and September 2018, the patients attended to Pediatric Hospital in Erbil City. The demographic data of these participants are shown in Table (1),
$110(36.67 \%)$ of the participant were males and $190(63.33 \%)$ of theme were females, 46 males (15.33\%) and 144 females (47.99\%) of them were school age children between 6 to 12 years old.

Table (2): Distribution of blood group, $\mathrm{Rh}$ and age of patients

\begin{tabular}{|c|c|c|c|c|c|c|}
\hline \multirow{3}{*}{$\begin{array}{c}\text { Developmental } \\
\text { stages }\end{array}$} & \multicolumn{4}{|c|}{ ABO Blood group } & \multicolumn{2}{|c|}{ RH factors } \\
\hline & $\mathbf{A}$ & B & AB & $\mathbf{O}$ & Positive & Negative \\
\hline & No. (\%) & No. (\%) & No. (\%) & No. (\%) & No. ( \%) & No (\%) \\
\hline Toddler stage & $21(7.0)$ & $16(5.33)$ & $2(.665)$ & $13(4.33)$ & $47(15.67)$ & $5(1.67)$ \\
\hline preschool age & $22(7.33)$ & $11(3.67)$ & $2(.665)$ & $23(7.67)$ & $55(18.33)$ & $3(1.0)$ \\
\hline School age & $44(14.67)$ & $49(16.33)$ & $12(4.0)$ & $85(28.33)$ & $126(42.0)$ & $64(21.33)$ \\
\hline Total & $87(29)$ & $76(25.33)$ & $16(5.33)$ & 121(40.33) & $228(76.0)$ & $72(24.0)$ \\
\hline
\end{tabular}

Table (2) showed distribution of blood groups among patients developmental stages, $121(40.33 \%)$ of the children have blood group $\mathrm{O}$ and majority of them were school aged children 85 (28.33\%), and most 228 $(76.0 \%)$ of cases have $\mathrm{Rh}$ positive, and the rest $72(24.0 \%)$ have $\mathrm{Rh}$ negative blood group among randomly selected cases. The percentages of other blood groups were 87 (29\%), 76 (25.33\%) and 16 (5.33\%) respectively for each $\mathrm{A}, \mathrm{B}$, and $\mathrm{AB}$ blood group. 
Association Between Typhoid and Paratyphoid Fever with ABO Blood Group among Patients Attending

Raparin Pediatric Hospital in Erbil

Table (3): Association between developmental stages, typhoid, and paratyphoid fever suffering children

\begin{tabular}{|c|c|c|c|c|c|c|}
\hline \multicolumn{4}{|c|}{$\begin{array}{c}\text { Typhoid Fever } \\
\text { Salmonella typhi (blood culturing) }\end{array}$} & \multicolumn{3}{|c|}{$\begin{array}{c}\text { Paratyphoid Fever } \\
\text { Salmonella paratyphi (blood culturing) }\end{array}$} \\
\hline Developmental stages & $\begin{array}{l}\text { Positive } \\
\text { No. }(\%)\end{array}$ & $\begin{array}{l}\text { Negative } \\
\text { No. }(\%)\end{array}$ & Total & $\begin{array}{l}\text { Positive } \\
\text { No. }(\%)\end{array}$ & $\begin{array}{l}\text { Negative } \\
\text { No. }(\%)\end{array}$ & Total \\
\hline Toddler stage & $0(0)$ & $52(17.335)$ & $52(17.33)$ & $0(0)$ & $52(17.335)$ & $52(17.335)$ \\
\hline Preschool age & $0(0)$ & $58(19.335)$ & $58(19.335)$ & $0(0)$ & $58(19.335)$ & $58(19.335)$ \\
\hline School age & $94(31.33)$ & $96(32)$ & $190(63.33)$ & $103(34.33)$ & $87(29)$ & $190(63.33)$ \\
\hline Total & $94(31.33)$ & $206(68.67)$ & $300(100)$ & $103(34.33)$ & $197(65.67)$ & $300(100)$ \\
\hline $\begin{array}{l}\text { P-value (df.) Sig at } \\
\text { level of } 0.05\end{array}$ & \multicolumn{3}{|c|}{$79.254(.000)$} & \multicolumn{3}{|c|}{$90.810(.0000)$} \\
\hline
\end{tabular}

Table (3) represented association between developmental stages, typhoid, and paratyphoid fever suffering Children. Among 300 blood samples were collected from patients for typhoid and paratyphoid fever analysis, 94(31.33\%) and 103 (34.33\%) cases were positive blood culture (typhoid) and the remaining $206(68.67 \%)$ and 197 $(65.67 \%)$ cases were negative culture growth respectively, all of positive culture growth cases were school aged. Significant association was found between developmental ages with typhoid fever children. 
Table (4): Association between blood group, Rh with typhoid and paratyphoid disease.

\begin{tabular}{|c|c|c|c|c|}
\hline \multicolumn{3}{|c|}{$\begin{array}{l}\text { Typhoid Fever } \\
\text { (Salmonella typhi) }\end{array}$} & \multicolumn{2}{|c|}{$\begin{array}{c}\text { Paratyphoid Fever } \\
\text { (Salmonella paratyphi) }\end{array}$} \\
\hline Blood group & $\begin{array}{c}\text { Culture positive } \\
\text { No. }(\%)\end{array}$ & $\begin{array}{l}\text { Culture negative } \\
\text { No. }(\%)\end{array}$ & $\begin{array}{l}\text { Culture positive } \\
\text { No. }(\%)\end{array}$ & $\begin{array}{l}\text { Culture negative } \\
\text { No. }(\%)\end{array}$ \\
\hline A & $17(5.67)$ & $70(23.335)$ & $18(6.0)$ & $69(23.00)$ \\
\hline B & $24(8.0)$ & $52(17.335)$ & $27(9.0)$ & $49(16.335)$ \\
\hline $\mathrm{AB}$ & $7(2.33)$ & $9(3.0)$ & $7(2.33)$ & $9(3.0)$ \\
\hline $\mathrm{O}$ & $46(15.33)$ & $75(25)$ & $51(17)$ & $70(23.335)$ \\
\hline Total & 94(31.33) & 206(68.67) & 103(34.33) & 197(65.67) \\
\hline P-value & \multicolumn{2}{|c|}{ Value : $9.284 X^{2}: .026$} & \multicolumn{2}{|c|}{ Value : 11.13 Va Value: $11.139 X^{2}: .011$} \\
\hline \multicolumn{5}{|l|}{$\mathrm{Rh}$ factor } \\
\hline Positive Rh & $51(17.00)$ & $177(59.00)$ & $54(18.00)$ & 174(58) \\
\hline Negative Rh & $43(14.33)$ & $29(9.67)$ & $49(16.33)$ & $23(7.67)$ \\
\hline Total & $94(31.33)$ & 206(68.67) & 103(34.33) & 197(65.67) \\
\hline P-value & \multicolumn{2}{|c|}{ Value: $35.486 X^{2}: .000$} & \multicolumn{2}{|c|}{ Value:: $47.785 X^{2}: .000$} \\
\hline
\end{tabular}

*The Chi-square (X2 statistic is significant at the .05 level.

Table (4) demonstrated association between blood group, Rh with typhoid and paratyphoid disease. According to blood group highest number of infection with typhoid $(15.33 \%)$ and paratyphoid (17\%) were among blood group O. Also lower percentage of infection with typhoid $(5.67 \%)$ and paratyphoid $(6 \%)$ were found in blood group A. Least percentage of infection were among blood group $\mathrm{AB}(2.33 \%$ and $2.33 \%$ ) correspondingly for each typhoid and paratyphoid.Significant association was found among blood group with each typhoid $(\mathrm{P}=0.26)$ and paratyphoid $(\mathrm{P}=0.011)$. Regarding to $\mathrm{Rh}$ high prevalence rate of each typhoid (17\%) and paratyphoid (18\%) were among $\mathrm{Rh}+$, lower percentage of typhoid $(14.33 \%)$ and paratyphoid (16.33\%) were found in Rh-. High significant association were found between $\mathrm{Rh}$ with each typhoid $(\mathrm{P}=0.00)$ and paratyphoid $(\mathrm{P}=0.00)$ disease.

\section{Discussion}

Since the discovery of the ABO blood group, there has been an ongoing interest in 
the potential role of blood groups in infectious disease.The association of blood groups with diseases was thought to concern the relation of the antigen of the infecting organisms with those of the blood group.

Blood groups are frequent targets in epidemiological investigations since they are genetically determined traits with known polymorphic expression among individuals and populations.

Many blood groups are receptors for toxins, parasites, and bacteria, where they can facilitate colonization or invasion or evade host clearance mechanisms. Blood groups can also serve as false receptors, preventing binding to target tissue. Finally, bacteria can stimulate antibodies against blood group antigens, including $\mathrm{ABO}$.

ABO antibodies can be considered part of the innate immune system against some bacterial pathogens and enveloped viruses that carry ABO-active antigens [12]. This study revealed that all of children that had positive typhoid (31.33\%) and paratyphoid $(34.33 \%)$ were school age children, typhoid and paratyphoid fever affected this age group because of poor sanitary condition in the school and contaminated food and drinking water.

Similar result was found in Previous studies which had demonstrated that the highest Salmonella typhi isolation rates in Kibera, were all among 10- 17 years old, and followed by 5-9 years old among cases of typhoid fever. This study suggest that because of large population density and severely limited option for sanitation and safe water, people live within urban slum in Africa and in Asia, are at higher risk for typhoid fever[13]. Other study which has been done in Asia, estimated typhoid fever incidence in China, India, Indonesia, Pakistan, and Vietnam in order to inform typhoid fever vaccine policy. This study confirmed the high incidence of typhoid fever in the region, particularly among children and adolescents, but also demonstrated that substantial variation in an incidence occurs between surveillance sites in the same region [14].

Another study was similar to our finding which designed to find out the prevalence of typhoid fever among the children living in Kamrangir char and its adjacent areas in the semi urban Dhaka Bangladesh from June 2009 to May 2010, they concluded that the prevalence of typhoid fever was high among the children of school going age, who consume unsafe drinking water and food from outside sources [15].

The probable association between infectious disease and $\mathrm{ABO}$ blood group is depend on its carbohydrate on RBC surface. This structure may act as a receptor for some virus, bacteria and parasite and mediate their entrance [16].

The result from this investigation of the association between $\mathrm{ABO}$ and $\mathrm{Rh}$ with typhoid and paratyphoid fever indicate that blood group $\mathrm{O}$ subjects are more susceptible to typhoid $(15.33 \%)$ and paratyphoid $(17 \%)$ fever. While the lowest level detected in AB blood type $(2.33 \%)$ for each typhoid and paratyphoid. The result shows significant 
association between ABO blood group and typhoid and paratyphoid fever. This result is in an agreement with previous studies. Otoikhia and Okoror17 reported in 2012 that the typhoid and paratyphoid attack was observed among blood group $\mathrm{O}$ while the least noticed among blood group $\mathrm{AB}$ individual. Other study was reported that $\mathrm{O}$ blood type was associated with typhoid and paratyphoid fever, blood group $\mathrm{O}$ showed least resistance for typhoid and paratyphoid fever18. Regarding the occurrence of typhoid and paratyphoid among blood group B (9\%) and $(8 \%)$ for each one, our result indicates resistance of B blood group to these diseases. While Amal and et al, found that there was no positive association between typhoid and paratyphoid with different blood group. However, when each group was individually considered, blood group B indicates there may be some positive association with typhoid and paratyphoid fever[19].

The distribution of typhoid and paratyphoid was much higher among $\mathrm{Rh}+$ children this result is compatible to those found by Carlos and Valenzuela. Also they concluded that individual with blood group $\mathrm{B}$ and $\mathrm{Rh}+$ was more susceptible to typhoid [20].

A study was carried out by Teddy and her coworkers assessed the prevalence of Salmonella antibodies in blood donated for transfusion and the associated risk, the investigator found that the rate of typhoid cases was highest among subjects with an $\mathrm{O}$ blood group (64.2\%). He also assumed that individuals with blood group $\mathrm{O}$ are more susceptible to Salmonella infections than individuals with other blood groups. They mentioned that individuals with blood group $\mathrm{O}$ are more vulnerable to certain diseases, particularly intestinal ulcer, than individuals with other ABO blood groups. He suggested that this susceptibility is due to the permeability of the intestinal wall in blood group $\mathrm{O}$ individuals. Incidentally, this aligns with the fact that Salmonella easily enters the intestinal wall cells of human host [21].

\section{Conclusions}

Typhoid is health problem in Erbil City among school age children, children should educate to drink/ eat safe water / food, Also our study concluded significant association between blood group and typhoid / paratyphoid fever, and researchers recommended more study to understanding the main role of blood group and risk of typhoid and paratyphoid infection.

\section{References}

[1]Crump JA, Luby SP, Mintz ED. The global burden of typhoid fever. Bull World Health Organ. 2004; 82: 346-353.

[2]Fangtham M, and Wilde $\mathrm{H}$. Emergence of Salmonella paratyphi A as a major cause of enteric fever: need for early detection, preventive measures, and effective vaccines. J Travel Med. 2008:15; 344-350.

[3]Thong KL, Cheong MY, Puthucheary S, Koh CL, Pang T. Epidemiologic analysis of sporadic Salmonella Typhi isolates and those from outbreaks by pulsedpulsed field gel electrophoresis. J Clin. Microbiol. 1994; 32:1135-1141.

[4]Fjaerli HO, Heger B, Gundersen SG, Hoet $\mathrm{T}$, Espinoza R. Outbreak of typhoid in 
family. Tidsskr nor Leageforen 1993; 113: 3022-4.

[5]World Health Organization6th International conference on Typhoid fever and other Salmonelloses. WHO Geneva 2006.

[6] Ravn V, and Dabelstein E. The ABO blood group system: historical background. Trans. Med.2000; 11: 243-262.

[7] Garratty G, Glynn SA, McEntire R. ABO and $\mathrm{Rh}(\mathrm{D})$ phenotype frequencies of different racial/ethnic groups in the United States. Transfusion. 2004; 44 (5): 703-706. [8] Reid $\mathrm{ME}$, and Bird GW, Associations between human red cell blood group antigens and disease. Transfusion Med. Rev. 1990; 4(1): 47-55.

[9]Sawsan M, Abdullah Al-Sorchee, Abbas A, Rabat, Intisar M Juma. Microbial Causatives of Diarrhea in Children in Erbil City. J Al-NahrainUniversity . 2013; 16 (3):19-29

[10]Olopoenia LA, and King AL. Widal agglutination test. 100 years later, St, Plagued by controversy, Post graduate Medical J. 2004; 760: 80-84.

[11]Cheesbrough,M. Districts laboratory practice in tropical countries. Cambridge University press, UK; 2006.P.62-70.

[12]Laura Cooling. Blood Groups in Infection and Host Susceptibility. JAMS. Org 2015; 28 (3): 1-70 .

[13] Robert F, Breiman and et.al. Population

- Based Incidence of Typhoid Fever in an Urban Informal Settlement and a Rural Area in Kenya: Implications for Typhoid Vaccine Use in Africa. Plos One J. 2012;7(1): 1-8.
[14] John A Crump and Eric D Mintz. Global Trend in Typhoid and Paratyphoid Fever. CIDJ. 2010: 15; 50(2): 241-246.

[15] Akmm AM, Begum RS, Hossain MZ, Hoque SA, Yeasmin LM. Prevalence of typhoid fever among the children in a semi urban area of Bangladesh, Dhaka medical coll j. 2011; 20(1): 37- 43.

[16]Omolbaninamjadi and et al. Blood Group: in Health and Diseases, research in Molecular Medicine J. 2015; 3(4): 1-9.

[17]Otoikhian CS, and Okoror LE. Prevalence of Typhoid and Paratyphoid, in Relation to Their Genotype Among Student of Novena University, Ogume. International Journal of Pharma Medicine and Biological Sciences. 2012;1(2): 217-224.

[18]EO, Igumbor and DO Osayanade. Bactericidal Activity of Human Sera AgainstSalmonella typhi and Salmonallaparatyphi. East African medical J. 2000; 77 (12): 676-680.

[19]Amal Kanti Banik, ATM Nurulkabir, Jahangir Alam. Children - a study in a Teriary Care Hospital , Dhaka, Bangladesh. J Dental and Medical Sciences. 2018; 17(9): 63-69.

[20] Carlos Y Valenzuela. ABO, Rh, MNSs, Sex and Typhoid Fever. Human Heredity J. 1993; 43: 301-310

[21] Teddy C Adias, Zaccheaus A jermiah., Ayo O. IIesanmi Distribution of antibodies to Salmonella in sera of blood donors in the south - western region of Nigeria. Blood Transfusion Journal. 2010; 8: 163-169. 